Explaining Patterns of Candidate Competition in Congressional Elections Author(s): Jeffrey S. Banks and D. Roderick Kiewiet

Source: American Journal of Political Science, Vol. 33, No. 4 (Nov., 1989), pp. 997-1015

Published by: Midwest Political Science Association

Stable URL: http://www.jstor.org/stable/2111118

Accessed: 18-03-2016 16:07 UTC

Your use of the JSTOR archive indicates your acceptance of the Terms \& Conditions of Use, available at http://www.jstor.org/page/ info/about/policies/terms.jsp

JSTOR is a not-for-profit service that helps scholars, researchers, and students discover, use, and build upon a wide range of content in a trusted digital archive. We use information technology and tools to increase productivity and facilitate new forms of scholarship. For more information about JSTOR, please contact support@jstor.org. 


\title{
Explaining Patterns of Candidate Competition in Congressional Elections*
}

\author{
Jeffrey S. Banks, University of Rochester \\ D. Roderick Kiewiet, California Institute of Technology
}

The low probability of defeating incumbent members of Congress deters potentially strong rivals from challenging them. Yet almost all incumbents are challenged, usually by opponents who lack previous experience in office and run underfinanced, ineffectual campaigns. But if strong challengers are deterred from challenging incumbents, why are not weak challengers, who have even less chance of unseating an incumbent?

The model developed in this paper indicates that there is a simple reason why weak candidates choose to run against incumbents: they do so in order to maximize their probability of getting elected to Congress. Together with the findings of previous researchers, the results of our analyses of congressional primary data from 1980 through 1984 provide strong support for the major hypotheses derived from our model.

\section{Previous Research: The Advantages of Incumbency}

Over the past two decades over $93 \%$ of incumbent members of Congress who seek reelection have been successful. This high success rate is in large measure due to the resources that incumbents possess. First, key institutional features of Congress allow incumbents to maximize the political benefits and to minimize the political risks entailed in making public policy (Mayhew 1974a). The division of legislative labor among dozens of standing committees and hundreds of subcommittees produces specialization of policymaking expertise and disaggregation of power. This facilitates the ability of incumbents to take personal credit for programs and policies that benefit their constituents and so boosts their reelection prospects. Second, the single-member district electoral system grants each incumbent a corner on the local market for "constituency service" or "case work" (Fiorina 1977, 1979). Representatives have voted themselves large staffs and office budgets in order to provide such services to their constituents. Third, incumbents can exploit the franking privilege to mail constituents large volumes of educational material, including vital information about what they have been doing for them lately (Cover 1978; Cover and Brumberg 1982). Incumbents also enjoy ready access to local mass media and thus a level of public

* We gratefully acknowledge Ed Green for the advice and assistance he gave us in the early stages of this research. Bruce Cain, Morris Fiorina, Will Jones, Sandy Maisel, Fred Thompson, Jack Wright, and especially Gary Jacobson provided valuable comments and criticisms on earlier versions of this paper. We would also like to thank Linda Donnelly and Pamella Easley for their assistance in data collection.

American Journal of Political Science, Vol. 33, No. 4, November 1989, Pp. 997-1015

(C) 1989 by the University of Texas Press, P.O. Box 7819, Austin, TX 78713 


\section{TABLE 1}

Nonincumbent Candidates in Congressional General Elections with Experience in Elective Office, 1972-84

(In Percentages)

\begin{tabular}{llllll}
\hline \hline & \multicolumn{2}{c}{ Incumbent Running } & & \multicolumn{2}{c}{ Open Seat } \\
\cline { 2 - 3 } \cline { 5 - 6 } Year & Dem. & Rep. & & Dem. & Rep. \\
\hline 1972 & 21.5 & 21.7 & & 41.4 & 51.7 \\
1974 & 38.3 & 12.6 & & 54.7 & 49.1 \\
1976 & 29.5 & 16.9 & 60.0 & 59.0 \\
1978 & 25.4 & 16.2 & & 50.0 & 44.2 \\
1980 & 25.4 & 14.6 & 62.2 & 51.4 \\
1982 & 39.1 & 15.4 & 73.6 & 62.3 \\
1984 & 19.4 & 13.1 & 60.9 & 60.9 \\
\hline
\end{tabular}

SourCE: The 1972-78 figures are from Jacobson and Kernell (1981, 32). Figures for 1980-84 are derived from data the authors obtained from Congressional Quarterly Weekly Report's coverage of congressional primary election.

exposure and awareness that nonincumbent candidates can only covet (Mann 1978; Mann and Wolfinger 1980).

As if this is not enough, the strategic environment of congressional elections appears to play to the incumbents' advantage. A large body of research indicates that incumbents do not usually face a strong challenger of the other party in the general election (Leuthold 1968; Huckshorn and Spencer 1971; Mann and Wolfinger 1980; Jacobson 1980a, 1980b). The most systematic evidence on this phenomenon is that reported by Jacobson and Kernell (1981). Their data indicate that men and women who have held a prior elective office (e.g., a seat in the state legislature) perform several percentage points better in contests against incumbent members of Congress than do challengers who lack such previous experience. Presumably, previous experience in office makes them stronger candidates by providing them with a higher degree of visibility, credibility, and thus more access to campaign contributions. High-quality candidates with previous experience in elected office, however, are far more likely to be found vying for an open seat than challenging an incumbent. This is shown by the figures in Table 1.

The relatively large percentages of Democratic challengers in 1974 and 1982 who had previously held an elected office indicates that inauspicious years spawn a larger number of strong challenges against incumbents of the president's party. Multivariable analyses of House races also have found that several indicators of incumbent vulnerability (poor economic conditions when 
the incumbent president is of the same party, a small victory margin in the previous election, or strong underlying support in the district for the opposite party) predict challenges by previously experienced, higher-quality candidates (Bianco 1984; Bond, Covington, and Fleisher 1985). Similarly, incumbents who have cast unpopular votes (e.g., against declaring war in 1.941 or against impeaching Nixon in 1974) can expect strong, well-funded opponents (Wright 1977; Mann 1978).

The obvious implication of Table 1, however, is that unless an incumbent is particularly vulnerable, potentially strong challengers prefer to wait on the sidelines until he dies, retires, or otherwise decides not to run for reelection. This implication is in fact so obvious that the full extent of such self-selection is documented for the first time in Table 2. In addition to strong challengers (those who had previously held an elected office) and weak challengers (those with no

TABLE 2

Rates of Participation by Different Types of Candidates in Congressional Primary Elections, 1980-84

\begin{tabular}{|c|c|c|c|c|c|}
\hline \multirow[b]{3}{*}{ Type of Primary } & \multicolumn{3}{|c|}{ Democrats } & & \\
\hline & \multicolumn{5}{|c|}{ Challenger Strength } \\
\hline & High & Medium & Low & All & $N$ \\
\hline Democratic incumbent & $\begin{array}{l}7^{\mathrm{a}} \\
(0.09)^{\mathrm{b}}\end{array}$ & $\begin{array}{c}1 \\
(0.01)\end{array}$ & $\begin{array}{l}38 \\
(0.54)\end{array}$ & $\begin{array}{l}42 \\
(0.65)\end{array}$ & 695 \\
\hline Republican incumbent & $\begin{array}{l}28 \\
(0.34)\end{array}$ & $\begin{array}{l}6 \\
(0.08)\end{array}$ & $\begin{array}{l}80 \\
(1.40)\end{array}$ & $\begin{array}{l}92 \\
(1.81)\end{array}$ & 417 \\
\hline Open seat & $\begin{array}{l}67 \\
(1.26)\end{array}$ & $\begin{array}{l}30 \\
(0.34)\end{array}$ & $\begin{array}{l}75 \\
(1.70)\end{array}$ & $\begin{array}{l}100 \\
(3.30)\end{array}$ & 113 \\
\hline \multicolumn{6}{|c|}{ Republicans } \\
\hline Republican incumbent & $\begin{array}{l}2 \\
(0.03)\end{array}$ & $\begin{array}{c}1 \\
(0.01)\end{array}$ & $\begin{array}{l}14 \\
(0.16)\end{array}$ & $\begin{array}{l}17 \\
(0.20)\end{array}$ & 421 \\
\hline Democratic incumbent & $\begin{array}{l}14 \\
(0.15)\end{array}$ & $\begin{array}{l}7 \\
(0.07)\end{array}$ & $\begin{array}{l}73 \\
(1.13)\end{array}$ & $\begin{array}{l}82 \\
(1.36)\end{array}$ & 691 \\
\hline Open seat & $\begin{array}{l}58 \\
(0.96)\end{array}$ & $\begin{array}{l}15 \\
(0.16)\end{array}$ & $\begin{array}{l}84 \\
(1.98)\end{array}$ & $\begin{array}{l}100 \\
(3.11)\end{array}$ & 113 \\
\hline
\end{tabular}

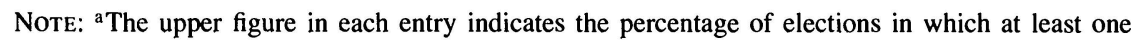
candidate of the type indicated was running.

${ }^{b}$ The number in parentheses is the average number of candidates of the type indicated in each type of primary election. 
previous political experience), we also assigned challengers to a "medium" strength category. Such candidates had either been congressional staffers, party officials, or had previously held a nonelected public office.

The figures in Table 2 bear out the intuitive interpretation of Table 1. The reason why incumbents generally do not face strong challengers is that under these circumstances such challengers choose not to run for their party's nomination in the first place. Weaker candidates demonstrate far less aversion to doing so. Indeed, at least one weak challenger showed up more often to challenge a Republican incumbent $(80 \%)$ than to contest an open seat $(75 \%)$. Open seats, however, attracted a slightly higher average number of weak Democratic challengers (1.70 compared to 1.40$)$. Challengers in this category were far more likely to take on an incumbent of their own party as well.

That potentially strong challengers should prefer to hold off running until the seat opens up is understandable enough. Such a contest promises to be a battle fought on roughly equal footing with an opponent similar to oneself in resources and experience. The odds of winning such a race are much higher, making a run at an open seat more appealing than the bleak prospects of unseating an incumbent. Most of the time, the opponent that an incumbent faces is instead an obscure figure who has never previously held an elected office. Thus while potentially stronger candidates are discouraged from running by the odds against unseating an incumbent, unknown and inexperienced challengers enter the fray, usually launching themselves, as Maisel (1982) puts it, from obscurity to oblivion. This pattern of competition, however, is a puzzling one. Formal models of competition as well as common sense indicate that weak opponents are deterred more readily than strong ones. Here, however, strong challengers are deterred from challenging incumbents while the weak are not. How can this be?

Previous research has suggested several answers to this question. These are probably best illuminated in terms of the conventional equation of political participation,

$$
R=p B-C+D
$$

in which $R$, the utility of engaging in a political act (e.g., voting, running for office) equals the benefits $(B)$ accruing from the act-in this case the benefits of election to Congress-times the probability $(p)$ that the act will yield the benefits, minus the costs $(C)$ of engaging in the act, plus the private consumption value $(D)$ of the act (Riker and Ordeshook 1973).

Most previous studies have relied heavily upon the existence of a large $D$ (private consumption) term to account for the greater willingness of weak challengers to take on incumbents. Many report that they knew they would almost surely lose such a race but ran in order to pursue other, nonelectoral goals. Other candidates claim to have taken on a hopeless campaign against an incumbent out 
of a sense of duty to their party; although they themselves had little chance of winning, they felt that they would aid the party's candidates for other offices who would otherwise be "pulled down" by the absence of a congressional candidate on the ballot (Kazee 1980).

Other explanations appeal to additional types of consumption. Candidates report that their campaign served as an excellent forum to present their views on major issues (Maisel 1982) or that running for office was a personally enriching experience (Kazee 1980). Yet another explanation is that a congressional campaign against an incumbent, though unsuccessful, yields material benefits such as publicity for one's legal practice (Leuthold 1968; Schlesinger 1966; Huckshorn and Spencer 1971, O'Neill 1987). ${ }^{1}$

We concur that the $D$ (consumption) term must loom large in the decision to run or not. Something has to separate the tiny handful of people who ever decided to run for Congress from the rest of us who have never given a thought to undertaking such an enterprise. But the sheer consumption value of running for office, no matter how high it gets, gives us no leverage in explaining the paradoxical pattern of weak candidates challenging incumbents while the strong are deterred. This would require additionally that weak candidates derive more consumption out of running than do potentially strong candidates. This seems dubious at best, given that potentially strong candidates, most notably those who have held previous elective office, are strong precisely because they have already chosen to devote a substantial part of their life to public affairs.

A more fruitful line of reasoning is that of Jacobson and Kernell, who argue that candidates with no previous office can be induced to challenge incumbents because they, unlike many potentially more formidable candidates, do not have to forfeit an office they presently hold to make a run for Congress. Furthermore, a defeat at the polls for someone at this stage of their political career is a damaging event from which it is very difficult to recover. Weak candidates, in other words, have a lower $C$ term in that they face lower opportunity costs. ${ }^{2}$ However, differential opportunity costs alone do not satisfactorily account for the paradoxical pattern of congressional competition that we are interested in explaining. Strong potential challengers who must forfeit an office they currently hold in

\footnotetext{
'Many suspect that Maisel made his unsuccessful bid for Congress in order to write a book about it. Maisel steadfastly denies this charge.

${ }^{2}$ Almost all of the 5,501 state representatives in the United States serve two-year terms and therefore must forfeit their seats to run for Congress. But a large majority of state senators serve four-year terms and technically could, in every other election year, run for Congress while retaining their seats. There are only 1,981 state senators in the country, however, so Jacobson and Kernell are correct in observing that most state legislators must forfeit their seat to run for Congress. (These data are reported in The Book of the States). It is also the case that high opportunity costs may dissuade challengers from running for Congress even under the most favorable of circumstances. Fowler and McClure (1989) found that certain members of the New York state legislature chose to hold onto their current jobs rather than to run for an open congressional seat that they had a good chance of winning.
} 
order to run for Congress must do so regardless of whether they are running for an open seat or challenging an incumbent. Similarly, the opportunity costs faced by weak candidates, even if they are relatively lower, presumably are not affected by the nature of the congressional race they choose to enter.

Indeed, even if all challengers face the same opportunity costs, and even if this cost is zero, another element in the decision calculus-the $p$ (probability) term - will lead different types of candidates to behave differently. For strong candidates a consideration of the relevant probabilities generally leads to an obvious course of action; knowing they are far more likely to win an open seat than to defeat an incumbent, they will be inclined to wait for the incumbent to step aside. Previous research has suggested that weak candidates who challenge incumbents, on the other hand, have deluded themselves into wishfully thinking that their probability of winning is much higher than it actually is (Leuthold 1968; Kazee 1980; Maisel 1982). Perhaps this is so. What we shall show, however, is that under certain circumstances weak challengers making accurate, unbiased probability estimates will choose to run against incumbents for the same reason strong challengers decide to wait for an open seat-to maximize the probability of their being elected to Congress.

Before proceeding, we would like to reiterate that the purpose of our analysis is not to denigrate the role that costs and private consumption considerations play in candidates' decisions to run or not to run. They clearly are very important. We believe, however, that all candidates, strong and weak, also condition their decisions upon accurate assessments of the odds they face in getting elected to Congress. It is these probability assessments, furthermore, that account for the paradoxical pattern of congressional competition. Specifically, rational, utility-maximizing candidates can generate an equilibrium in which weak candidates challenge incumbents while strong candidates wait for an open seat.

The key to understanding why this may be the case is the fact that to get to Congress candidates must do more than win the general election in their district. They must first defeat any and all other opponents from their own party in the primary election. For little-known candidates who have never previously held an elected office, the inclusion of both these parameters into the decision calculus may lead to a higher expected utility from running against an incumbent rather than waiting for an open seat. We will now sketch out a simple perfect information model involving an incumbent and two potential challengers, one weak and one strong, to illuminate this argument.

\section{A Simple Model of Congressional Election Competition}

For the following model, we shall assume that there exist two potential challengers, $C_{1}$ and $C_{2}$ of the same party, and an incumbent $C_{l}$ of an opposing party. Candidates $C_{1}, C_{2}$, and $C_{l}$ are assumed to be risk neutral, and it is known with certainty that $C_{I}$ will retire after one more term in office. At time $t=1$, both $C_{1}$ and $C_{2}$ decide whether to enter a campaign against the incumbent, while 
at $t=2$, they decide whether to run for the open seat. To operationalize the notion of "strong" and "weak" opponents, we let challenger $C_{i}$ possess a quality level $q_{i}$, where $q_{i}$ is a function of $C_{i}$ 's currently held office, previous political and electoral experience, and so forth. Let $q_{2}>q_{1}$, where a higher quality level indicates a higher probability of defeating the incumbent, ceteris paribus. We also assume that (1) each challenger can run in only one general election, ${ }^{3}$ and (2) if either challenger wins at $t=1$, the other will not challenge their incumbency at $t=2$.

At the time of the first entry decision, the outcome of the general election is uncertain; however, we can assume that the outcome will be a function of the quality of the challenger, $q_{i}$, and a number of incumbent-specific parameters such as $C_{I}$ 's voting record $R, C_{I}$ 's district-wide exposure $A$, and $C_{I}$ 's amount of casework $W$. These parameters can be represented by a vector $y=\left(y_{1}, y_{2}, y_{3}\right)$ in $\mathbf{R}_{+}^{3}$, where $y_{1}=R, y_{2}=A, y_{3}=W$. Let $\theta$ be a random variable with distribution $H(\theta)$, which describes the randomness of the electoral outcome. The plurality for $C_{i}$, conditional on entry and winning the primary, is

$$
x_{i 1}\left(\theta, q_{i}, y\right)=V_{i 1}\left(\theta, q_{i}, y\right)-V_{I 1}\left(\theta, q_{i}, y\right)
$$

where $V_{j t}$ is the percentage vote for $j$ at time $t$. We can suppress $\theta$ and treat $x_{i 1}$ as a random variable with distribution $F\left(x_{i 1} ; q_{i}, y\right)$, where, given $H(\theta), F(\cdot)$ is the distribution induced by the relationship $x_{i 1}=x_{i 1}\left(\theta, q_{i}, y\right)$. The support of $F(\cdot)$ is $[-1,1]$, since $x_{i 1}$ is a plurality vote, and setting

$$
p_{i 1}\left(q_{i}, y\right)=1-F\left(0 ; q_{i}, y\right)
$$

we have that $p_{i 1}\left(q_{i}, y\right)$ is the probability that $C_{i}$ defeats the incumbent at $t=1$. Similarly, let $p_{i 2}$ be the probability that $C_{i}$ defeats the expected candidate in the general election at $t=2$, conditional on entry and winning the primary.

We assume that both challengers have a higher probability of winning the open seat at $t=2$ than the incumbent-occupied seat at $t=1$ :

$$
p_{i 1}<p_{i 2}, \frac{\partial p_{i 1}}{\partial y}<0, \quad i=1,2,
$$

and that at both $t=1$ and $t=2$ the high-quality challenger has a higher probability of winning the general election:

$$
\frac{\partial p_{i t}}{\partial q_{i}}>0, \quad t=1,2
$$

Similarly, we can derive the probability $\pi_{2}\left(q_{1}, q_{2}\right)$ of $C_{2}$ prevailing in a primary contested by $C_{1}$, where we assume that

${ }^{3}$ For the sake of convenience, we allow the possibility for a challenger who lost a primary at $t=1$ to run again at $t=2$. The restriction that candidates may suffer only one general election defeat, however, serves to inform the prior decision as to whether or not to enter the primary. 


$$
\frac{\partial \pi_{2}}{\partial q_{1}}<0, \frac{\partial \pi_{2}}{\partial q_{2}}>0, \pi_{2} \in(.5,1)
$$

We assume that challenger $i$ has preferences defined over general election results and represented by von Neuman-Morgenstein utilities $U_{i}^{w}, U_{i}^{l}, U_{i}^{n}$, corresponding to $i$ winning, losing, and not entering the general election, respectively. For the high-quality challenger, $C_{2}$, we assume that $U_{2}^{w}>U_{2}^{n} \geqslant U_{2}^{l}$, where without loss of generality we set $U_{2}^{n}=0$. For the low-quality challenger $C_{1}$, we assume that $U_{1}^{w}>U_{1}^{n}=U_{1}^{l}$, where again we set $U_{1}^{n}=0$. Hence, the opportunity cost of running in the general election is zero for $C_{1}$ (except at $t=1$, where this precludes running at $t=2$ ) and is nonnegative for $C_{2}$, so that it is possible that neither challenger suffers a loss in utility from running in a general election. ${ }^{4}$

If $C_{i}$ wins the primary at time $t$, he or she receives an expected utility at time $t$ of

$$
\alpha_{i t} \equiv p_{i t} U_{i}^{w}+\left(1-p_{i t}\right) U_{i}^{l}
$$

We assume that $\alpha_{i 2}>0, i=1,2$, so that both challengers will run at $t=2$ if they did not lose the $t=1$ general election. This allows us to focus attention on the decision of whether or not to run at $t=1$. In particular we wish to generate conditions under which $C_{1}$ entering and $C_{2}$ not entering constitute Nash equilibrium behavior.

If $C_{1}$ enters at $t=1, C_{2}$ will not enter if

$$
\left(1-p_{11}\right) \alpha_{22}>\pi_{2} \alpha_{21}+\left(1-\pi_{2}\right)\left(1-p_{11}\right) \alpha_{22}
$$

Any necessary condition for equation (7) to hold would require knowledge about the values of $U_{2}^{w}, U_{2}^{l}, U_{2}^{n}$; however, we can generate sufficient conditions for equation (7) using only $p_{11}, p_{21}$, and $p_{22}$. Expanding out equation (7) and rearranging terms, we get

$$
\left(U_{2}^{w}-U_{2}^{\prime}\right)\left[\left(1-p_{11}\right) p_{22}-p_{21}\right]>U_{2}^{\prime} p_{11}
$$

Since $U_{2}^{\prime} \leqslant 0$ and $U_{2}^{w}-U_{2}^{\prime}>0$, a sufficient condition for equation (8) to hold is that

$$
\left(1-p_{11}\right) p_{22}>p_{21}
$$

Note that this condition is not a function of $\pi_{2}$. For example, suppose that $p_{22}=$ .5 and $p_{21}=.3$; since $p_{11}<p_{21},\left(1-p_{11}\right)>.7$, so that equation (9) holds, and $C_{2}$ has an incentive to wait, regardless of the utility or the probability $\pi_{2}$ of prevailing in the primary. Applying the same logic, we also see that equation (9) and

${ }^{4}$ Subsequent results hold if $U_{1}^{l}$ is sufficiently close to $u_{1}^{n}$, or if $U_{1}^{l}>U_{1}^{n}$, so that $C_{1}$ actually gains from the experience. Otherwise the conditions will be a function of the utility levels. 


$$
\pi_{2} p_{22}>p_{21}
$$

imply that it is a dominant strategy for $C_{2}$ to wait until $t=2$ to enter the race.

Given that $C_{2}$ does not enter at $t=1, C_{1}$ will enter if

$$
U_{1}^{w}\left[p_{11}-\left(1-\pi_{2}\right) p_{12}\right]>0
$$

or

$$
p_{11}>\left(1-\pi_{2}\right) p_{12}
$$

Thus, equations (9) and (12) provide sufficient conditions for $C_{1}$ to be the sole challenger against the incumbent at $t=1$. Of course, since we have not specified any of the parameters in the model, it may be that the quality levels of $C_{1}$ and $C_{2}$ are sufficiently close to generate another Nash equilibria where only $C_{2}$ enters at $t=1$. However, when equations (9) and (10) are satisfied, the only challenge to the incumbent at $t=1$ (if there is one) will be from a weak challenger. Furthermore, by equation (5), this becomes more likely the lower the quality of this challenger. It is also apparent from equation (3) that equations (9) and (10) are more likely to be satisfied the higher the incumbent's quality. Thus higher-quality incumbents are "rewarded" with a higher probability of facing a low-quality challenger.

Suppose now that $C_{1}$ and $C_{2}$ are concerned only with the probability of being elected rather than with their expected utility. If so, $C_{2}$ will prefer not to run at $t=1$, given $C_{1}$ is running at $t=1$, if

$$
\left(1-p_{11}\right) p_{22}>\pi_{2} p_{21}+\left(1-\pi_{2}\right)\left(1-p_{11}\right) p_{22}
$$

Canceling terms, we see that equation (7) re-creates precisely the condition which obtains in equation (9). A similar condition holds for equation (12). In other words, $C_{1}$ entering at $t=1$ and $C_{2}$ not constitutes a Nash equilibrium in this "probability" game. But these strategies will also be a Nash equilibrium in the "expected utility" game. This implication underlies the empirical examination of the model below, for it permits us to make predictions about candidate behavior solely upon the basis of estimated probabilities of winning under different scenarios.

First, however, we shall draw out a simple example to illustrate the logic of this model. Suppose it is known that a Republican incumbent will serve one more term before retiring. In the Democratic ranks, there are two potential challengers. The first is a state senator whose district largely coincides with the congressional district; the second, an attorney who has never campaigned for nor been elected to public office. Assume the probability of the lawyer defeating the incumbent is the average success rate weak candidates running against incumbents have had over the past decade-5\% - while the state senator has a $13 \%$ chance of dumping the incumbent. Assume also that, having won the primary, the state 


\section{TABLE 3}

A Game between Two Challengers of the Same Party:

Summary of Hypothetical Probabilities

\begin{tabular}{lrrrr}
\hline & $A$ & $B$ & $C$ & $A \times B \times C$ \\
\hline Probability of $S$ getting elected if: & & & & \\
$S$ runs now, $W$ runs now & .90 & .13 & 1.00 & .117 \\
$S$ runs now, $W$ runs next time & 1.00 & .13 & 1.00 & .130 \\
$S$ runs next time, $W$ runs now & 1.00 & .43 & .95 & .409 \\
$S$ runs next time, $W$ runs next time & .90 & .43 & 1.00 & .387 \\
& & & & \\
Probability of $W$ getting elected if: & & & & \\
$W$ runs now, $S$ runs now & .10 & .05 & 1.00 & .005 \\
$W$ runs now, $S$ runs next time & 1.00 & .05 & 1.00 & .050 \\
$W$ runs next time, $S$ runs now & 1.00 & .24 & .87 & .209 \\
$W$ runs next time, $S$ runs next time & .10 & .24 & 1.00 & .024 \\
\hline
\end{tabular}

NoTE: $A=$ probability of winning the primary.

$B=$ probability of winning the general election.

$C=$ probability that the incumbent was not previously defeated.

senator would have a $43 \%$ chance of winning an open seat in this district, compared to $24 \%$ for the lawyer. ${ }^{5}$ Although the lawyer would have only a small (10\%) chance of defeating the state senator in a Democratic primary, both candidates would be certain to win if they ran unopposed. Both know that if one waits for the open seat and the other does not, there is a chance that the other will defeat the incumbent. If this happens, the candidate who waited will be precluded from running in the second election against the new incumbent of his own party. The opportunity costs and consumption benefits for both challengers are the same whether they run now or run later, and so we shall ignore them for present purposes. We assume only that the net costs and consumption benefits for both do not rule out a run for Congress entirely.

These probabilities are summarized in Table 3. The term $S$ refers to the strong challenger (the state senator); $W$, to the weak challenger (the lawyer); $A$ is the probability of winning the primary; $B$, the probability of winning the general election; and $C$, the probability that the incumbent was not previously defeated by the other challenger.

${ }^{5}$ The probabilities used in this example were calculated by Gary Jacobson (personal communication) in a probit analysis of 1970-84 congressional election data in which he assumed neutral national tides and the presence of an incumbent who received $65 \%$ of the vote in the previous election. We are indebted to him for making these figures available to us. 
As indicated above we can describe the payoffs to this game simply in terms of the product of probabilities $A \times B \times C$. These are reported in Figure 1 . The first payoff listed in each cell is for the strong challenger; the second, for the weak.

In this example the strong challenger has a dominant strategy: wait to run for the open seat. Regardless of what the weak challenger does, the strong challenger's probability of getting elected is higher than if he or she were to run now. Because of the slim chance of winning a contested primary, the weak challenger's best strategy is to run whenever the strong challenger is not running and thus sail through the primary unopposed. The weak challenger would of course prefer the strong challenger to run now against the incumbent, while he or she waited to run for the open seat. The young lawyer knows, however, that the strong challenger will wait for the open seat regardless of what he or she does.

To some it may seem implausible (or at least ironic) to develop a rational choice model in which weak challengers bother to run at all given their low probability of success. Maybe so, but the probabilities assumed in this example were derived from the actual record of the past several years. We thus know the odds are favorable enough to provoke a challenge in nearly every congressional election. Our model simply holds that weak challengers can maximize their probability of getting to Congress by running now against the incumbent. This probability may not be very high, but they are maximizing it.

It should also be noted that in the simple strategic environment portrayed by our model there can be several strong potential challengers present before any of them have an incentive to run against the incumbent. Assume, for example, that there are three candidates with the same general election prospects as the strong challenger here (a $13 \%$ chance of defeating the incumbent, a $43 \%$ chance of taking the open seat) and that each has a 33\% chance of winning a primary in which they all participated. Each would still have a higher probability of getting to Congress by waiting for the open seat than by challenging the incumbent.

FIGURE 1

Payoff Matrix of the Game between Two Challengers

Weak

Challenger

\begin{tabular}{|c|c|c|c|}
\hline \multirow{3}{*}{$\begin{array}{c}\text { Strong } \\
\text { Challenger }\end{array}$} & \multirow{3}{*}{$\begin{array}{l}\text { Run Now vs. } \\
\text { Incumbent } \\
\text { Run Next Time } \\
\text { for Open Seat }\end{array}$} & $\begin{array}{c}\text { Run Now vs. } \\
\text { Incumbent }\end{array}$ & $\begin{array}{c}\text { Run Next Time } \\
\text { for Open Seat }\end{array}$ \\
\hline & & $11.7 \%, 0.5 \%$ & $13.0 \%, 20.9 \%$ \\
\hline & & $40.9 \%, 5.0 \%$ & $38.7 \%, 2.4 \%$ \\
\hline
\end{tabular}




\section{Empirical Examination of the Model}

According to the model we have developed, the paradoxical pattern of strong candidates being deterred by the presence of an incumbent from the other party, while weak candidates are not, is actually a product of their utilitymaximizing decisions. No matter what the weak challenger does, the strong challenger is better off waiting for the open seat. Knowing that waiting gives little chance of beating the strong challenger in a primary, the weak challenger runs now, confident that he or she can at least get the nomination and thus the outside chance it confers at toppling the incumbent.

There are a couple of things which should be kept in mind in evaluating the empirical performance of our model. First, the model gives only the conditions under which it makes sense for weak candidates to challenge incumbents while the strong do not. Other conditions will dictate other strategies. The point of our empirical analysis, then, is to determine whether or not weak candidates typically do face circumstances similar to those given in equations (9) and (12)circumstances which will induce them to run against an incumbent rather than wait for an open seat. If so, we shall have an explanation for the paradoxical pattern of congressional election competition. Second, it should also be kept in mind that previous experience in elected office is a coarse measure of candidate quality. Many state legislators are not very formidable candidates for Congress, and many candidates who have never held office possess other resources that make them high-quality candidates. ${ }^{6}$ Personal wealth can obviate the hazards of fund-raising, and there are many careers outside of politics which produce a high level of visibility - sports, space flight, television, and selling cars, to name a few. ${ }^{7}$

As was shown in the previous section, our analysis can proceed by considering only the probability terms that guide candidates' decisions. The record of the last several years indicates that the probability of an incumbent falling to a challenger with no previous experience in office is only about $5 \%$. If so, the weak challenger's rationale for accepting these odds depends crucially upon the premise that the odds of beating a strong challenger in the party's primary are

${ }^{6}$ It might seem that we could examine the implications of our model directly by categorizing challengers as weak or strong on the basis of previous elected office and then comparing their rates of success in contests against incumbents versus elections to an open seat. This would simply require computing the conditional probability terms listed in Table 3. Such a procedure, however, would be invalidated by the self-selection predicted by our model. Candidates with experience in elected office who nevertheless challenge incumbents are the weakest of the strong. Candidates with no previous experience in office who run for open seats would correspondingly be the strongest of the weak.

${ }^{7}$ Actually television exposure is no guarantee of electoral success in the congressional arena. Fred Grandy was able to parlay his previous career (playing Gopher on The Love Boat) into a victory in Iowa's Sixth District in 1986. However, Nancy Kulp (Miss Jane Hathaway on The Beverly Hillbillies) was trounced in her run for Pennsylvania's Ninth District seat in 1984. 
also extremely unfavorable. The first task in gauging the empirical merits of our model is thus to determine just how successful weak candidates have been in primary contests against strong candidates. To make this calculation, we again turned to the data we gathered from the Congressional Quarterly Weekly Report. From their coverage of congressional nomination contests between 1980 and 1984, we were able to obtain the requisite data on 1,225 pairs of congressional nomination contests (almost all were primaries, but a few states still use state conventions) for a total of 2,450 observations. This represents $94 \%$ of the congressional primary contests held in these three years.

Table 4 reports the percentages of weak challengers who managed to win their party's nomination despite the fact that it also was being sought by at least one strong challenger. As before, individuals with a prior elected office on their resumé are considered strong. Those without one are considered weak. As these figures indicate, weak challengers were seldom able to prevail in the face of competition from strong challengers. This happened in only $11.2 \%$ of such cases in our data set-a figure very close to the hypothetical probability of $10 \%$ used in our illustrative sample. Nor did it seem to matter much whether the candidates were Democrats or Republicans or whether the winner would go on to face an incumbent or to vie for an open seat.

Furthermore, our model implies that the $11.2 \%$ success rate that we calculated from these data is misleadingly high. This is because the presence of one or more strong candidates in a contest should have deterred some weak candidates from entering. Our model implies that relatively weak candidates who decided to run under such circumstances should have higher quality levels than those who did not. The challengers in our weak category, then, would be the strongest of the weak.

Having determined that it would make abundant good sense for weak challengers to avoid primary contests against stronger opponents, the task to which we now turn is to determine if they in fact do so. According to our model, the greater willingness of weak challengers to run against incumbent representatives derives from a desire to avoid being pitted against one or more strong challengers

\section{TABLE 4}

Weak Challengers Who Win Congressional Primaries When Opposed by One or More Strong Challengers, 1980-84

(In Percentages)

\begin{tabular}{lcc}
\hline \hline Type of Primary & Democrats & Republicans \\
\hline Challenge of an incumbent & 12.7 & 16.0 \\
Open seat & 10.2 & 7.6 \\
\hline
\end{tabular}


in the primary. If so, we should observe that weak candidates are less likely to enter primary elections that are also being contested by strong candidates. This hypothesis constitutes a critical test for our model.

Results of this test are reported in Table 5. These figures reveal clear evidence of the hypothesized deterrent effect. Weak challengers of both parties were much more likely to appear in primaries when strong challengers were absent. This is true when the primary winner went on to face an incumbent of the other party, as well as when the seat was open. The only comparison that failed to bear out this prediction was that involving the average number of weak Republican candidates in open seats. All other comparisons were in the predicted direction and significant at the .05 level or better. The paradoxical pattern of self-selection in which strong candidates are deterred by incumbents while the weak are not can thus be accounted for by a prior, more readily understood pattern of selfselection in which weak candidates are deterred by strong candidates of their own party.

An additional observation worth making here is that strong candidates failed to enter a surprisingly large number (over a third) of the open seat primaries in

\section{TABLE 5}

The Effect of the Presence of Strong Candidates upon the Number of Weak Candidates in Congressional Primary Elections, 1980-84

\begin{tabular}{lllll}
\hline \hline & \multicolumn{4}{c}{ Democrats } \\
& \multicolumn{4}{c}{ Strong Challenger Present } \\
\cline { 2 - 5 } Type of Primary & Yes & No & Combined & $N$ \\
\hline Challenge of an incumbent & $58^{\mathrm{a}}$ & 89 & 80 & 417 \\
& $(1.01)^{\mathrm{b}}$ & $(1.54)$ & $(1.40)$ & \\
Open Seat & 66 & 95 & 75 & 113 \\
& $(1.55)$ & $(2.00)$ & $(1.70)$ & \\
& & & & \\
Challenge of an incumbent & Republicans & & 73 & 691 \\
& 47 & 77 & $(1.13)$ & \\
Open Seat & $(0.82)$ & $(1.18)$ & 84 & 113 \\
& 73 & 100 & $(1.98)$ & \\
\hline
\end{tabular}

Note: ${ }^{a}$ The upper figure in each entry indicates the percentage of elections in which at least one weak candidate was running.

${ }^{\mathrm{b}}$ The number in parentheses is the average number of weak candidates in each type of primary election. 


\section{TABLE 6}

Previous Experience of Candidates Elected to the House, 1970-84:

Challenges of Incumbents Compared to Open Seat Elections

\begin{tabular}{lccr}
\hline \hline & \multicolumn{3}{c}{ Type of Election } \\
\cline { 2 - 4 } Political Background & Incumbent Running & Open Seat & $N$ \\
\hline State office & 25.3 & 74.7 & 265 \\
City or county office & 39.1 & 60.9 & 87 \\
Appointed public position & 66.6 & 33.3 & 15 \\
Congressional staffer & 13.6 & 86.4 & 22 \\
Former representative & 60.0 & 40.0 & 20 \\
Party official & 42.9 & 57.1 & 28 \\
No previous office & 56.6 & 43.4 & 113 \\
\hline
\end{tabular}

our sample. Conversely, these contests attracted large numbers of weak candidates. We suspect there are a couple of factors that largely account for this. First, not every open seat portends an evenly matched contest between the two parties' nominees. In an overwhelmingly Democratic district, for example, the Republican nomination is not worth much even when there is no incumbent running. Consequently, the Republican primary will not attract strong candidates, assuming that a strong Republican candidate even exists. Second, in some elections the incumbent, due to death, illness, or other reasons, drops out unexpectedly after primary filing dates have passed. But because potentially strong challengers had expected the incumbent to run and had thus chosen not to run themselves, a weak challenger is able to win the primary and therefore to run for an open seat.

The pattern of candidate competition that we have so far analyzed has important consequences for the nature of the candidates who are ultimately elected to Congress and for the paths they followed to get there. Table 6 displays data on the backgrounds of the 550 members elected to their first term in the House of Representatives between 1970 and 1984. Because of the larger number of observations possible, we are able to break these data down into finer categories than the dichotomy based upon whether or not the candidate had previously held an elected office. These figures show that nearly $75 \%$ of the successful House candidates who had previously held state-level office got to Congress by winning an open seat. Former staffers were also more likely to have chosen the strategy of running for an open seat-usually the one vacated by their boss.

The less impressive their previous office, however, the more likely candidates were to have been elected to Congress by not waiting for an open seat. County or city officeholders were more likely to have done so than state office- 


\section{TABLE 7}

Previous Congressional Election Losses Suffered by

Candidates Elected to the House, 1970-84

\begin{tabular}{lrr}
\hline \hline & \multicolumn{2}{c}{$\begin{array}{c}\text { Previous } \\
\text { Congressional } \\
\text { Election Loss }\end{array}$} \\
\cline { 2 - 3 } Political Background & \multicolumn{1}{c}{ Yes } & No \\
\hline State office & 8.6 & 91.4 \\
City or county office & 9.0 & 91.0 \\
Minor office & 20.0 & 80.0 \\
Congressional staffer & 0.0 & 100.0 \\
Former representative & 40.0 & 60.0 \\
Party official & 24.1 & 75.9 \\
No previous office & 25.4 & 74.6 \\
Average for all candidates & 14.0 & 86.0 \\
\hline
\end{tabular}

holders, and a large majority of those who had only held either a minor office or no office at all won their seat by defeating an incumbent. Finally Table 6 reveals that for over $20 \%$ of all members initially elected to Congress in this period, this was the first office to which they had ever been elected. A large majority of these members, furthermore, got there by defeating an incumbent.

There is one additional issue in the congressional election literature that we have so far addressed only in passing. Many candidates who have been elected to Congress in recent decades had made an unsuccessful attempt before succeeding (Fenno 1978). This suggests that it is possible for an inexperienced challenger to enhance future political prospects by running a losing but impressively strong race against an incumbent (Huckshorn and Spencer 1971). Or, in terms of our model, a weak candidate, by doing much better than expected against an incumbent, can transform him- or herself into a higher-quality candidate, thereby setting the stage for a successful challenge next time. ${ }^{8}$ Even better, a strong

${ }^{8}$ Strong challengers, of course, are simply those candidates who have improved their quality level by climbing the political ladder fewer rungs at a time (e.g., first, city council, then the state house, then, they hope, Congress). The probability of becoming a strong challenger via this route is thus the probability of winning a series of lesser offices. The probability of eventually getting to Congress may be higher this way, but it takes longer and requires serving in positions less prestigious and rewarding than that of congressional representative. Candidates whose first try for elected office is for Congress are apparently more risk acceptant and/or more ambitious; Rohde (1979) found that members who first got to Congress by challenging and defeating an incumbent are more likely to try subsequently for a seat in the Senate. 
challenge may persuade the incumbent that the office is not worth another costly fight which might end in embarrassing defeat and that retirement is preferable. In this case the formerly weak challenger will be in an excellent position to win the open seat (Squire and Smith 1984).

Our data shed some light on this issue as well. As the figures in Table 7 indicate, less than $10 \%$ of the ultimately successful House candidates who had previously held state, county, or city office had also sustained a prior defeat in a congressional election. In contrast, about one fourth of those in the weakest two categories (those who had held only a minor office or no office at all) built a successful campaign upon a previous defeat. These data also revealed that in nine instances candidates from the weakest two categories won an open seat after an earlier loss to an incumbent. Their margins of defeat were quite small-eight of the nine had garnered more than $45 \%$ of the vote. Although redistricting was a proximate cause for the retirement of several incumbents, this evidence indicates to us that the strong challenges they had experienced also encouraged them to retire. Initially weak challengers thus appear to be able to improve their quality by coming close to knocking off an incumbent, which of course makes the strategy of challenging an incumbent rather than waiting for an open seat even more attractive.

\section{Conclusion}

Previous research has suggested several reasons why weak candidates challenge incumbent members of Congress when potentially stronger candidates are deterred. It is argued that such candidates misperceive the odds against them or that they are actually using a congressional campaign to pursue goals other than winning office. Another possibility is that weak candidates may be induced to run at lower probabilities of winning because their political opportunity costs are low or because a stronger than expected showing may serve as an investment in future campaigns.

All of the above reasons surely contribute to the decisions of unknown, inexperienced candidates to run for Congress, but provide little insight as to why such candidates should choose to run against incumbents when potentially much stronger challengers are deterred. This paper has argued that given the strategic situation they face, challenging an incumbent may maximize the probability of their being elected to Congress. This is because the current incumbent is not the only opponent potential that challengers must take into account. To get to Congress, they must first defeat any and all other candidates of their own party. The likelihood of defeating an incumbent representative is low, but a candidate who chooses to challenge an incumbent is more likely to avoid serious opposition in the primary. A candidate who instead waits for a seat to open up faces the additional hurdle of winning a primary against one or more strong candidates of his 
own party. For unknown, inexperienced candidates, the prospects of getting to Congress may be better in the former situation than in the latter.

\section{Manuscript submitted 8 September 1987 \\ Final manuscript received 13 February 1989}

\section{REFERENCES}

Bianco, William T. 1984. "Strategic Decisions on Candidacy in U.S. Congressional Districts." Legislative Studies Quarterly 9:351-64.

Bond, Jon R., Cary Covington, and Richard Fleisher. 1985. "Explaining Challenger Quality in Congressional Elections." Journal of Politics 47:510-27.

Council of State Governments. 1980. The Book of the States, 1980-81. Lexington, KY: Council of State Governments.

Cover, Albert D. 1977. "One Good Term Deserves Another: The Advantage of Incumbency in Congressional Elections." American Journal of Political Science 21:523-41.

Cover, Albert D., and Bruce S. Brumberg. 1982. "Baby Books and Ballots: The Impact of Congressional Mail on Constituent Opinion." American Political Science Review 76:347-59.

Fenno, Richard F. 1978. Home Style: House Members in Their Districts. Boston: Little, Brown. Fiorina, Morris P. 1977. "The Case of the Vanishing Marginals: The Bureaucracy Did It." American Political Science Review 71:177-81.

1979. Congress: Keystone of the Washington Establishment. New Haven: Yale University Press.

Fowler, Linda, and Robert D. McClure. 1989. Political Ambition: Who Decides to Run for Congress. New Haven: Yale University Press.

Huckshorn, Robert J., and Robert C. Spencer. 1971. The Politics of Defeat. Amherst: University of Massachusetts Press.

Jacobson, Gary C. 1980a. "Candidates, Campaigns, and Contexts in Congressional Elections." Presented at the annual meeting of the American Political Science Association, Washington, DC.

1980b. "Congressional Elections: The Case of the Vanishing Challengers." Presented at the Conference on Congressional Elections, Houston.

Jacobson, Gary C., and Samuel Kernell. 1981. Strategy and Choice in Congressional Elections. New Haven: Yale University Press.

Kazee, Thomas A. 1980. "The Decision to Run for Congress: Challenger Attitudes in the 1970s." Legislative Studies Quarterly 5:79-100.

Leuthold, David A. 1968. Electioneering in a Democracy. New York: Wiley.

Maisel, L. Sandy. 1982. From Obscurity to Oblivion: Congressional Primary Elections in 1978. Knoxville: University of Tennessee Press.

Mann, Thomas E. 1978. Unsafe at Any Margin: Interpreting Congressional Elections. Washington, DC: American Enterprise Institute.

Mann, Thomas E., and Raymond E. Wolfinger. 1980. "Candidates and Parties in Congressional Elections." American Political Science Review 74:617-32.

Mayhew, David R. 1974a. Congress: The Electoral Connection. New Haven: Yale University Press.

- 1974b. "Congressional Elections: The Case of the Vanishing Marginals." Polity 6: $295-317$.

O'Neill, Tip. 1987. Man of the House: The Life and Political Memoirs of Speaker Tip O'Neill. New York: Random House. 
Riker, William H., and Peter C. Ordeshook. 1973. An Introduction to Positive Political Theory. Englewood Cliffs, NJ: Prentice-Hall.

Rohde, David W. 1979. "Risk-Bearing and Progressive Ambition: The Case of Members of the United States House of Representatives." American Journal of Political Science 23:1-26. Schlesinger, Joseph. 1966. Ambition and Politics. Chicago: Rand McNally.

Squire, Peverill, and Eric R. A. N. Smith. 1984. "Repeat Challenges in Congressional Elections." American Politics Quarterly 12:51-70.

Wright, Gerald C. 1977. "Constituency Response to Congressional Behavior: The Impact of the House Judiciary Committee Impeachment Votes." Western Political Quarterly 30:401-10. 